\title{
The Principle of 'Damage' as Guidance for Civil Society Roles in Islamic Built Environment
}

\author{
Sharifah Fadylawaty Syed Abdullah, Mohd Dani Muhamad, Ezani Yaakub, Kamariah Yusoff \\ Academy of Contemporary Islamic Studies (ACIS), \\ Universiti Teknologi MARA, 40450 Shah Alam Selangor, Malaysia
}

fadylawaty4935@uitm.edu.my, mdani393@uitm.edu.my, ezani907@uitm.edu.my, kamar143@uitm.edu.my Tel: +60199320469

\begin{abstract}
Uncontrolled urbanization harms both the environment and society. Sole environmental responsibility has diminished the community's sense of responsibility. In this way, Local Agenda 21 aims to engage all parties, including civil society. This paper will explore the 'Damage' principle in relation to the environmental roles of civil society. Content from Kitab al-I'lan Bi Ahkam Al-Bunyan was analyzed. The findings revealed several figh-related essences related to civil society roles. A sustainable built environment requires policymakers and society to reexamine community involvement levels, types, and forms.
\end{abstract}

Keywords: Civil society; built environment; fiqh; 'Damage.'

eISSN: 2398-4287 @ 2021. The Authors. Published for AMER ABRA cE-Bs by e-International Publishing House, Ltd., UK. This is an open access article under the CC BYNC-ND license (http://creativecommons.org/licenses/by-nc-nd/4.0/). Peer-review under responsibility of AMER (Association of Malaysian Environment-Behaviour Researchers), ABRA (Association of Behavioural Researchers on Asians) and cE-Bs (Centre for EnvironmentBehaviour Studies), Faculty of Architecture, Planning \& Surveying, Universiti Teknologi MARA, Malaysia. DOI: https://doi.org/10.21834/ebpj.v6iSI6.3040

\subsection{Introduction}

Allah SWT bestows nature as a gift to humans. Humans, as Allah's caliph, must adequately govern and manage this universe. Pollution, erosion, vandalism, exploitation, natural disasters, extinction, biodiversity, and ecological imbalances have all been caused by profit-driven urbanization and a disregard for religious (Klarin, 2018).

Akbar evaluates a property's condition based on the actions or regulations of those who own, use, or control it. He argued that 19thcentury Ottoman codification of property laws shifted authority and responsibility from the individual to the state, destabilizing the traditional relationship between these concerned parties (Akbar, 1988). The implication is that individual roles and neighbourhood collaboration are obliterated, unlike in traditional practice (Besim Selim Hakim, 2019a). Society thinks that caring for the environment is the fundamental role of the government (Akbar,1988). As a result, various issues arose facing most Islamic countries, such as dirty, vandalism and insecurity.

Local Agenda 21 and several national policies are addressing this issue. The term 'Local Agenda 21' (LA21) refers to the overarching goal established for local communities by Chapter 28 of the Earth Summit Action Plan for Sustainable Development in Rio de Janeiro in 1992. Participation is a crucial feature of LA21 that sets it apart from previous environmental policy initiatives (Coenen, 2009).

Civil society is referred to as the "third sector", which play an essential role in maintaining environmental sustainability. From an Islamic perspective, the roles of civil society are guided by Islamic jurisprudence, known explicitly as figh. Thus, the objective of this paper is to identify the significance of the 'Damage' principle discussed in Kitab Al-I'lan Bi Ahkam Al-Bunyan as guidance to connect the roles of civil society to environmental and natural sustainability challenges.

eISSN: 2398-4287 @ 2021. The Authors. Published for AMER ABRA cE-Bs by e-International Publishing House, Ltd., UK. This is an open access article under the CC BYNC-ND license (http://creativecommons.org/licenses/by-nc-nd/4.0/). Peer-review under responsibility of AMER (Association of Malaysian Environment-Behaviour Researchers), ABRA (Association of Behavioural Researchers on Asians) and cE-Bs (Centre for EnvironmentBehaviour Studies), Faculty of Architecture, Planning \& Surveying, Universiti Teknologi MARA, Malaysia.

DOI: https://doi.org/10.21834/ebpj.v6iSl6.3040 


\subsection{Literature Review}

\subsection{The Concept of Civil Society}

The World Bank defines civil society as "a set of voluntary, non-profit organizations that exist in communities and value each other's contributions." It includes large and small NGOs, indigenous peoples, religious communities and multi-religious organizations, activists, and social movements. They unite for a common goal (World Bank 2020).

According to many researchers, civil society plays a vital role in modern society and is a significant change agent. In the 1980s, as many Eastern European countries became democratic and the EU disintegrated, civil society themes began to dominate the Western academic discourse. The Soviets are also slowly becoming democratic. Most countries define the fall of autocratic governments as a civil society victory over the state.

\subsection{Islam and Civil Society}

Some Western orientalists and secular Arab thinkers agree that Islam impedes growth and civil society development over time, whether in the east-central or Muslim-majority countries. They claim Islamic law is totalitarian and thus prevents the development of strong community institutions capable of counteracting past government oppression in Europe. Several other scholars disagree, citing a long history of civil society in Islamic cities. The term "unity" refers to the mujtama's institutions, such as guilds (trade group alliances), the awqaf (community service organization), and the group religion (Florian Zemmin,2018). These organizations have jurisdiction over their members, have independent powers, and are not subject to state authority (Harmsen, E. 2008). In reality, secular political power in the Islamic Arab world oppressed Muslims and Islamic public institutions. Freedom in the Arab-Islamic world can only be reclaimed with the rise of Islam in society (Harmsen, E.2008).

Islamic religious principles, such as taqwa, are among the best values to practise to maintain civil and state integrity (Ramazan Yildirim, 2018). In contrast, Western civilizations lack this value, separating religious teachings from worldly affairs. This perspective promotes harmful behaviours such as consumerism, individualism, racism, violence, and fanaticism, all of which can harm civil society. Religious piety, according to al-Ghannuchi, is the only way to achieve social balance (Harmsen 2008). Historically, Islamic intellectuals defined civil society as centred on religion and culture. As defined by al-Farabi, Ibn Miskawayh, and Ibn Khaldun, civilized society is achieved through collaboration and inner justice among the people and the government, which is always concerned with their welfare. (Bakar, 1997). In short, civil society is a holistic view of man, society, and nation-building based on Islamic teachings, with the primary goal of becoming an Islamically developed country.

\subsection{Civil Society and Environmental Preservation from Islamic Perspective}

Following are some implications of ignoring civil society responsibilities in environmental and built environment care:

\section{a) Unfavorable Urbanization}

Most Malaysian cities currently replicate Western urban planning, architecture, and habitat development (Hakim, 2007). The majority of Malaysian municipalities are built on the British concept of planning. It was colonized by several Western powers, including France, Italy, Spain, and even the Netherlands (Hakim, 2007). The same thing happened in Tunisia, Morocco, and Egypt when colonialists replaced Islamic construction with culturally rooted nature-based construction, alienating our own culture.

\section{b) Rising Pollution Rates}

Today's environmental devastation in Islamic countries is heartbreaking as we are now experiencing water, air, and land pollution:

i. Water pollution occurs due to two significant sources of pollution in rivers and the sea. Pollution of rivers caused by littering, sewage from industrial or residential areas, and sediments from forest clearing for development or logging (Amran \& Jamin, 2021). The problem worsens when there are no rules or standards for pollution from agricultural farm activities, such as pigs, cattle, goats, and sheep farming (Suhaimi Suratman \& Tahir, 2013). Meanwhile, oil spills and shipping activity in the Malacca Strait and the South China Sea pollute the sea (Buang, 2017).

ii. Air pollution caused by transport, industry, waste disposal, forest and peatland burning, especially during drought seasons (Ibrahim et al., 2016).

iii. Land-based pollution resulted from unregulated waste discharges, toxic waste dumping, mining, and logging (Ibrahim et al., 2016). Consequently, it will affect the soil fertility, spread infectious diseases like Covid-19, soil erosion and flash floods (Muslimah, S.Si, 2017).

Environmental preservation is highly emphasized in Islam, and we must keep nature clean, safe, and sustainable for present and future generations. In Islam, environmental protection is a religious obligation which will be rewarded, not an option (Salem et.al, 2012). This sacred responsibility is also debated in-depth in Kitab Al-I'lan Bi Ahkam Al-Bunyan. In traditional Islamic neighbourhood management, 
the community is responsible for environmental preservation. Meanwhile, under the institution ofhisbah and the role of qadhi, the authorities have jurisdiction over monitoring, enforcement, and judgement in community disputes (Besim S Hakim, 2007a; Besim S Hakim, 2010).

Based on the traditional implementation, it is essential to re-apply this sense of religious responsibility in contemporary society, reviewed from the perspective of fight for the community's common good.

Islam places a premium on the role of social movements in bringing about pro-social and pro-environmental change (Mohamed, 2012). For instance, fiqh books focus on waste management, cleaning and emptying sewage tanks, and handling inbound and outbound water sources (Besim Selim Hakim, 2017).

There is also a discussion of waqf-based neighbourhood facilities provided by the local community for shared use (Sholihah \& Zaenurrosyid, 2021). Human actions that disturb the peace and harmony of the environment are immoral, sinful, and punishable in Islam. Thus, the above religious responsibilities should be discharged appropriately following Islam.

\subsection{Methodology}

The data for this study came from a fiqh book, Kitab Al-I'lan Bi Ahkam Al-Bunyan. Using content analysis, the researcher identified vital themes relating to the principle of 'Damage' as a guide for civil society roles in the built environment, comprising fiqh, harm, dharar, sources, and responsibility. This research employs both inductive and deductive content analysis. An inductive method is a logical approach to providing broad explanations based on specific observations. To develop a theoretical explanation of the results, the researcher uses an inductive approach. Inductive data analysis collects data, interprets it, and then concludes it. In contrast, the deductive approach or method uses a logical process that begins with a general conclusion to produce a specific one, i.e. starting from a general question to a specific statement. The data obtained from kitab will then be carefully analyzed to produce more detailed information. Researchers use this method to express conclusions about the principle of 'Damage' in the built environment. The data validation is accomplished via triangulation with other relevant resources.

\subsection{Findings}

\subsection{Kitab Al-I'Lan Bi Ahkam Al- Bunyan}

Ibnu al-Rami, a Tunisian mason, wrote Kitab Al-I'lan bi Ahkam Al-Bunyan. Many legal opinions and judgments on various urbanism and construction issues written by Maliki scholars from North Africa and Al-Andalus are included. He made significant contributions to this burgeoning area by producing this comprehensive treatise on building and urban codes and related regional customary laws by referring to the previous and current work and local opinions and practices. In terms of construction and space, Ibn al-Rami's manuscripts contain five chapters, consisting of:

1. Buildings and walls.

2. Avoiding harm or damage.

3. Building flaws.

4. Plantations and the conflicts that arise between farmers who construct towers.

5. Grindstones

The manuscript later became a primary source for studies on the city's Islamic law relationships. Apart from the legal field, this document on the city benefited urban history, archaeology, and sociology during this period. The current author has extensively studied this treatise's rationale and prominent cases.

\subsection{The principle of 'Damage'; Guidance for civil society roles on the built environment based on Kitab Al-l'Lan Bi Ahkam Al- Bunyan}

Strict building codes are essential in controlling human behaviour, especially in densely populated cities. Humans should not build or create a property that encroaches on the property of others. Surveillance is also required to ensure that the structure produced is safe for society. So, based on the discussion from Kitab al-l'lan bi Ahkam Al- Bunyan, this section will discuss the principle of 'Damage'.

'La Dharar Wa La Dhirar' (No harm and no reciprocal harm) is a hadith narrated by Ahmad \& Ibn Majah (hadith no. 2431). All actions, dharar or dhirar, are forbidden in Islam. The causes of harm can be auditory, visual, or physical, affecting themselves, their neighbors, property, or dignity. Ibn Ar-Rami categorizes auditory harm into two types: vibration-related and non-vibration-related. Most Muslim scholars do not think the noise is harmful. Scholars agree that the sound made by a blacksmith or cotton carder is not forbidden, as stated by Ibn Habib and the Murattaf. The lack of danger produced against their income-generating priority justifies not prohibiting such activities. Unlike vibration, most jurists agree that mills and blacksmiths should be avoided if they are likely to harm neighbours.

Similarly, all noise interference from the enclosed horses (stable) is apparent and must be eliminated. Scholars agree that tanning animal skins are prohibited, considering the risks of odour. Smoke and odours from public baths, bakeries, and factories are also banned in the home. Unpleasant odour sources, such as toilets near homes, should be avoided. The odour should be contained as much as possible. Various activities can cause physical harm to a neighbour's property. Building toilets is one of the actions to avoid because it damages the walls. Ibn Qassem and Ibn Nafi say this is forbidden. However, according to Ibn Rushd, this act is unaffected.

Close-by barns, horse stables, mills, and blacksmith shops (forge bellows) should be prohibited. His movements would wake up the neighbours, and his urine could be harmful. Unless it is proven that the builder intends to injure a neighbour, Ibn Attab advises avoiding all threats. Trees encroach on neighbouring homes, contributing to community disputes. A tree that threatens a neighbour's property 
should not be felled if it existed before the house. If neighbours complain that the damage is likely to affect them, the authorities may order the owner to remove the wall. That is, the owner of the wall must obey. If a complaint is filed against the owner, the owner must compensate for the damages caused to humans, animals, or other adjacent dwellings.

Yahia claims compensation is due even if no witnesses or a complaint are present. According to Ashhab and Sahnun, the wall owner must compensate for damages even if no one complains or witnesses. According to lbn al-Rami, jurists categorize dharar (injury) into two types: existing and new. Sahnun, on the other hand, will consider damage as old until it is proven to be new. However, Ibn al-Hindi and Ibn Ziad present opposing views. If someone objects to a completed construction project because they believe it is unsafe, they must swear that their silence does not mean they allowed it to be completed.

The owner should be encouraged to take appropriate steps to prevent or remove harm caused by one's property to another. According to Ibn Qassem and Ibn Attar, if a person is aware that something unsafe is harming him but does not object within ten (10) years, no further objections are allowed. Others disagree with the right to object and the time frame. A person's right to object, for example, expires after fifteen (15) years, whereas Sahnun only allows for four to five years.

\subsection{Discussion; Roles of Civil Society Towards the Built Environment}

Debated in the Kitab Al-I'Lan Bi Ahkam Al-Bunyan is how a neighbourhood community should collectively play that role. It includes safeguarding others' interests while exercising rights. From the discussion on the principles of 'Damage' above, the researcher can extract some crucial essences relating the relevant viewpoints as guidance in empowering the role of civil society in the built environment. It includes:

a) Any built-environment action should consider the impact on others and the environment. The public interest should trump personal interests. Generally, harmful behaviour should be avoided. However, when it comes to livelihood, some fuqaha' suggest tolerance. Assume responsibility, change habits, and avoid adverse environmental attitudes. Islam places a high value on personal environmental responsibility.

b) Islam highly values the sharing of rights, togetherness, and responsibility for the future human population and environment. So, civil society should emphasize efficient conservation, management, and allocation. Systematic management is similar to the fighiyyah method, which seeks to avoid harming others, especially close neighbours.

c) The Kitab al-Illan Bi Ahkam Al-Bunyan debate demonstrated that environmental protection is a religious obligation, not a choice. As stated by Seyyed Hossein Nasr (1987), "environmental ethics... cannot occur without a focus on Divine law... Shariah is ultimately the obligation of all Muslim males and females". As religious orders, Islamic civil society would undoubtedly strive to improve the environment (habitat).

d) People must understand the built environment's figh (figh al-bunyan) as part of Shariah manifestation, which controls human conduct. This is in line with Ibn Khaldun's claim in the Book of Muqaddimah that Shariah control is the best way to inspire people to do good deeds, including environmental preservation. It comes from internal rather than from outside. Re-empowering Rabbani thought via fighiyyah is required. Quality of life can only be achieved if humans adopt an Islamic conservationist lifestyle. These two ideas are intertwined to protect life, people, and other creatures from calamity and pain caused by man's irresponsible actions.

e) To apply the Islamic ideals of environmental management as elaborated in Kitab Al-I'lan Bi Ahkam Al-Bunyan holistically, the Muslim community must deeply understand and appreciate them. The application of Islam must be strengthened because religious consciousness motivates Muslims to act according to Islamic law. Muslims must understand which actions are required, prohibited, disapproved, or recommended to put these teachings into practice.

f) Individual Muslims who uphold Islamic values will act to conserve and protect the environment. Individual action leads to collective community participation and engagement in environmental sustainability to achieve sustainable development based on Islamic jurisprudence.

The essence of the 'Damage' principle in empowering the role of civil society in the built environment was presented in Figure 1.

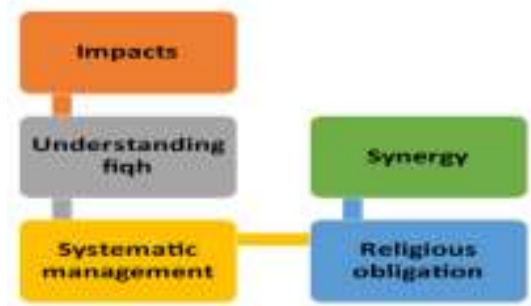

Fig. 1: Applications of 'urf in traditional Islamic built environment

(Source:) Author, 2021

\subsection{Conclusion}

This article achieved its goal by discussing 'Damage' from a figh perspective, emphasizing its importance with civil society roles in addressing today's environmental issues. This discussion takes a holistic, realistic, and proactive approach to understand Islamic jurisprudence. The findings of this study are highly relevant to community involvement in environmental conservation from a figh perspective for future sustainability. 
Due to the lack of resources discussing the role of civil society in the built environment from a fiqh perspective, future research should focus on Kitab related to figh al-bunyan. Muslims are encouraged to lead non-governmental organizations (NGOs) that implement Shariah in the current natural and built environments. This vital task requires collaboration from all parties, including the government, society, and individuals. This study adds the body of knowledge in understanding the significance of fiqh to empower roles of civil society in Malaysian Islamic built environment.

\subsection{Acknowledgements}

The authors highly appreciate the funding and support from the Research Nexus UiTM (ReNeU), Office of Deputy Vice Chancellor (Research and Innovation), Universiti Teknologi MARA, 40450 Shah Alam, Selangor under the MEE program (Mentor, Enforce \& Execute).

\section{References}

Akbar, Jamel (1988). Crisis in the Built Environment: The Case of the Muslim City. Singapore: Concept Media.

Amran, I. R., \& Jamin, R. M. (2021). Kajian pencemaran air terhadap komuniti Orang Asli. Universiti Malaysia Terengganu Journal of Undergraduate Research, 3(2), 119128.

Buang, A. (2017). Selat Melaka 1992-2006: Iktibar beberapa aspek permasalahan dalam mengurus kesejahteraan sumber sekitaran serantau (The Malacca Strait 1992 2006: Revisiting the challenge of managing a regional environmental resource). Geografia-Malaysian Journal of Society and Space, 2(1), 58-71.

Egbert Harmsen. (2008). Islam, civil society and social work; Muslim Voluntary Welfare Associations in Jordan Between Patronage and Empowerment. Amsterdam University Press. Amsterdam.

F.H.J.M. Coenen. (eds). (2009). Public participation and better environmental decisions, the promise and limits of participatory processes for the quality of environmentally related decision-making. New York. Springer.

Florian Zemmin. (2018). The concept of 'society' in the Journal al-Manar (Cairo, 1898-1940), in Modernity in Islamic tradition. De Gruyter.

Hakim, Besim Selim. (2019). Nature of Islamic urbanism and its Lessons. In B. S. Hakim (Ed.), Urban Rules and Process: Historic Lessons for Practice EmergentCityPress.

Hakim, Besim Selim (2010). The generative nature of Islamic rules for the built environment (International Journal of Architectural Research: ArchNet-IJAR, 4(1), 208-212. https://doi.org/10.26687/archnet-ijar.v4i1.72

Hakim, Besim Selim. (2007c). Revitalizing traditional towns and heritage districts. International Journal of Architectural Research: ArchNet-IJAR, 1(3), 153-166. https://doi.org/10.26687/archnet-ijar.v1i3.26

Hakim, Besim Selim (2010). The generative nature of Islamic rules for the built environment. International Journal of Architectural Research: ArchNet-IJAR, 4(1), 208-212. https://doi.org/10.26687/archnet-ijar.v4i1.72

Harmsen, E. (2008). Islam, civil society and social work. Amsterdam University Press. Amsterdam.

https://www.pewforum.org/2006/04/27/islam-and-the-west-a-conversation-with-bernard-lewis

Ibrahim, M. H., Leh, F. C., Adnan, M., Kalsum, N., \& Isa, M. (2016). Pencemaran habuk di Malaysia: mengesan taburan konsentrasi PM10di pusat bandar, sub bandar dan pinggir bandar di Ipoh, Perak. Geografia: Malaysian Journal of Society \& Space, 12(5), 104-114.

Klarin, T. (2018). The concept of sustainable development: From its beginning to the contemporary issues. Zagreb International Review of Economics and Business, 21(1), 67-94. https://doi.org/10.2478/zireb-2018-0005

Muslimah, S.Si, M. S. (2017). Dampak Pencemaran Tanah Dan Langkah Pencegahan. Jurnal Penelitian Agrisamudra, 2(1), 11-20. https://doi.org/10.33059/jpas.v2i1.224

Osman Bakar. 1997. Agama dan budaya teras masyarakat madani. Jurnal Usuluddin, [S.I.], 5, 1-10. https://ejournal.um.edu.my/index.php/JUD/article/view/3154

Othman, M. R., Talib, M., Latif, H., Samat, A., \& Sulaiman, M. S. (2006). Kesan aktiviti penanaman padi terhadap kualiti air. The Malaysian Journal of Analytical Sciences, 10(2), 233-242.

Ramazan Yildirim. (2018). Transformation of the Ennahda Movement from Islamic Jama'ah to Political Party. Insight Turkey. Vol. 19, No. 2, Ak Party 15 Years In Power Political, Economic And Social Transformation (Spring 2017), pp. 189-214. Set Vakfi İktisadi.

Suhaimi Suratman, \& Tahir, N. M. (2013). Kesan antropogenik terhadap kualiti air di Lembangan Sungai Marang, Perairan Selatan Laut China Selatan. Sains Malaysiana, 42(6), 743-751.

Sholihah, H., \& Zaenurrosyid, A. (2021). Islamic philanthropy development model based on management of waqf treasure improvement on the mosques of the Northern Seaboard of Java. Proceedings of the 2nd Southeast Asian Academic Forum on Sustainable Development (SEA-AFSID 2018), 168, 63-70. https://doi.org/10.2991/aebmr.k.210305.012

World Bank. (2021). Civil society. https://www.worldbank.org/en/about/partners/civil-society/overview 